\title{
Immunomodulating and zootechnical effect of some bacterial components on broiler chicken vaccinated with Newcastle disease vaccine
}

\author{
M. F. El-Kady ${ }^{\text {* }}$, S. M. Tamam², Azza A. El Sawah ${ }^{1}$, A. Okasha ${ }^{1}$ \\ ${ }^{I}$ Department of Poultry Diseases and ${ }^{2}$ Department of Virology, Faculty of Veterinary Medicine, \\ Beni-Suef University
}

\begin{abstract}
This study was carried out to evaluate the immunomodulating effects of, inactivated cells of Propionibacterium acnes and cell wall lipopolysaccharide (LPS) of the a pathogenic $E$. coli (INMUNAIR $\left.{ }^{\circledR} 17.5\right) 0.5 \mathrm{ml} / \mathrm{L}$ and 1 -3, 1 -6 $\beta$-glucans $\left(\right.$ BETAPOLO $\left.^{\circledR}\right) 1 \mathrm{ml} / \mathrm{L}$ on the immune response of chickens to Newcastle disease (ND) vaccine. The results showed that administration of IMR before vaccination was resulted in food conversion rate (FCR) higher than after vaccination . Significantly higher NDV HI antibody titers in IMR and Betapolo medicated groups as compared with control groups which in turn induce high protection rate in challenge test .Thymus, spleen and bursal indices of control negative showed significantly lower values than vaccinated medicated and non- vaccinatedmedicated groups $(P \leq 0.05)$.
\end{abstract}

Commercial poultry flocks receive a lot number of vaccines to protect them from environment pathogens, therefore, a great efforts had been expanded to develop strategies for enhance chicken immune response, especially in face of an immunosuppression caused by extraneous agents, infections, intoxication or by certain vaccine viruses. Immunomodulation could improve vaccinal immunity and possibly selectively promote responses that are critical for protection.

Immunomodulators usually classified according to their origin into biological and chemical products (Poli, 1984). This classification further broken down into physiological products, substances of microbial origin and synthesis compounds

Lipopolysaccharide (LPS) from cell wall of gram negative bacteria have immunostimulatory activity on lymphocyte and macrophage (Jacobs, 1981), increasing feed conversion (Vanjaykumer et al., 1983), activation of macrophage and enhance interferon production (Chihara et al., 1983). This work was designed an experiment to evaluate the immunomodulating effect of two immunotherapeutic products Inmunair ${ }^{\circledR}$ and Betapolo ${ }^{\circledR}$ on chicken, performance parameters and immune response to Newcastle disease vaccine. Criteria for evaluation was based on body weight gain, HI and challenge tests, bursal,

\footnotetext{
* Corresponding author. Tel.: +20 01231012 80;

Fax: +200822327982

E-mail address: mfelkady@bsu.edu.eg

(Magdy F. Elkady).
}

thymic and spleen body weight ratio.

\section{Materials and methods}

Immunostimulants a-INMUNAIR ${ }^{\circledR} \quad \mathbf{1 7 . 5}$ (IMR). It's a commercial water grade product (Batch No 17/60 supplied by Laboratorios Calier, U.S.A) formed from two bacterial components, inactivated cells of Propionibacterium acnes and lipopolysaccharide (LPS) from the cell walls of the apathogenic Escherichia coli. The product was used in drinking water at rate of $0.5 \mathrm{ml} / \mathrm{L}$.

Betapolo ${ }^{\circledR}$. It's a peataut composed of $(1-3,1-6)$ $\beta$-glucans produced(DMJ Biotech coporation. Wolsan-ri640 Nam-myeon, yeongi-gun, Chungnam, nm Korea Lot No: BP- 6007), it was used in drinking water at rate of $1 \mathrm{ml} / \mathrm{L}$.

Chicks. 250 one-day-old Arbor acres plus broiler chicks were used. The chicks were obtained from commercial hatchery of Miser ElArbia poultry Company.

Newcastle disease (ND) vaccinal strains. Hitchiner $\mathrm{B}_{1}$ and La Sota strains (Pfizer International Company, USA) were used after titration for vaccination of experimental chicks via eye instillation route.

Clone 30. vaccine nobilis clone 30 (Lot No: 06829AJ01, Intervet international B.V. Boxmeer -Holland) was used for vaccination of experimental chicks via eye instillation.

Velogenic NDVs. A local velogenic viscerotropic Newcastle disease virus (vvNDV) isolate (Shible and Reda, 1976) was kindly supplied by Newcastle Diseases Department; Veterinary Serum \& Vaccine Research Institute, 
Abbasia, Cairo, Egypt to be used for challenge test.

Haemagglutination (HA) and Haemagglutination inhibition (HI) tests. HA and HI test were carried out according to (Anon, 1971).

Bursa body weight index. It was calculated according to (Ying et al., 2003) as following. Bursa: body weight ratio = bursa weight/ body weight. Bursal index $=$ Bursa: body weight ratio X 1000 .

Challenge test. Chickens were intra muscularly with a dose of $0.5 \mathrm{ml} /$ bird containing $10^{6} \mathrm{EID}_{50}$ vvNDV according to (Afify, 1990). Birds with persisted symptoms till the end of the observation period were considered as dead.

Statistical analysis. Statistical analysis of variance (ANOVA) test was used to estimate differences among treatments according to (Steel and Torrie, 1960).

Experiment design. The used 250 chicks were randomly divided into 5 equal groups (1-5); 50 chicks each, from the $1^{\text {st }}$ moment of their arrival. Each group was kept in floor of clean, disinfected and separate room and feed on balanced commercial ration without antimicrobial feed additives.

IMR was added to water of both groups 3 and 4 at the $1^{\text {st }} 3$ days of life and reused for another 3 successive days at 17-19 and 21-23 days of life respectively. While the Betapolo was added to drinking water of group 5 for the 1 day every 3 days till the day 32 of life. Birds of groups 1 and 2 were kept as non-medicated control groups.

All chicken groups were received individually both inactivated avian influenza (AI) H5N1 vaccine subtype via S/C and IBD life vaccine via eye drop at the $5^{\text {th }}$ and $14^{\text {th }}$ day of life respectively. Chicks of groups 2-5 were farther vaccinated against ND using colone 30 at the $10^{\text {th }}$ and $20^{\text {th }}$ day of life; while birds of group 1 was kept as non-medicated, non-ND vaccinated control group.

Weekly 10 blood samples were individually collected for sera (1-7 weeks age).The sera were tested for HI antibody levels against. At the $10^{\text {th }}$, 19 th and $30^{\text {th }}$ days of life birds / group were collected randomly weighted and scarified with collection of bursa, spleen and thymus for detection of their weights. Birds of all groups were weighted at the $2^{\text {nd }}$ day ( 0 week) and weekly till the $7^{\text {th }}$ week for recording of weekly body weight gain and collection of total feed conversion rate.
At the $35^{\text {th }}$ day of life; 15 day post last ND vaccination 20 chicks/ group were subjected to challenge test. Challinged birds were subjected to daily observation for 7 days with recording of signs, mortalities and postmortem lesions in dead birds.

\section{Results and Discussion}

In the last 40 years a great efforts had been done aiming to find a numbers of immunestimulatory agents that are capable of stimulating the immune response of birds to face immunosuppression and vaccination failure, which constitute a challenge to poultry industry in Egypt and all over the world. The application of immunostimulant is not only to raise the resistance of the birds but also to improve the immune response to vaccination (Afify, 1990 and Awaad et al., 2000). Treated groups presented significant differences at $(\mathrm{p}<0.05)$. control 1588 gm, Betapolo ${ }^{\circledR} 1660$ gm and there is no significant difference between experimental and recommended dose of Inmunair ${ }^{\circledR} 1780 \mathrm{gm}$, 1776 gm, respectively (Table 1). The results in tables (3) revealed significant differences $(p<0.05)$ on the $10^{\text {th }}, 19^{\text {th }}$ and $30^{\text {th }}$ day old birds thymus index with Inmunair ${ }^{\circledR}$ and Betapolo ${ }^{\circledR}$ as compared with untreated birds. Greater spleen weights were seen in poultry treated with Inmunair ${ }^{\circledR}$ and Betapolo ${ }^{\circledR}$ (table 4 ) than those of untreated birds. Differences are significant on 10 day and 19 day-old, confirming the role of this organ in immune status of chicks, from the second week of life. In comparison between bursal weight of treated group with Inmunair ${ }^{\circledR}$ and Betapolo ${ }^{\circledR}$ with the untreated one, it was greater in the treated group, with significant differences $(p<0.05)$ on the 19 day and 30 day old birds. The results observed in lymphoid index confirming previously obtained results (Anguera et al., 1996; Ying et al., 2003). Data presented in Table (2,6 and 7) showed the results of HI titer for NDV vaccine in different chicken groups and its effect on challenge with vvNDV where group that received Inmunair ${ }^{\circledR}$ and Betapolo ${ }^{\circledR}$ showed significant higher NDV genomatric mean HI titer $(6.4,5.4)$ and $(5.9)$, respectively at 35 days of age. For Betapolo ${ }^{\circledR}$ (Fleischer et al., 2000; Acevedo et al. 2001) observed increased humoral response to ND with B-glucan. While Inmunair ${ }^{\circledR}$ contains LPS and inactivated cells of Propionibacterium acnes, our results agree with the observations (Flo et al., 1996). This indicates that the interaction of the LPS with the immune system causes B lymphoproliferation and a differentiation of B- 
lymphocytes, which is manifested by immunoglobulin synthesis increasing antibody response. The inactivated cells of Propionibacterium acnes play an important role increasing lymphocyte traffic, the increased antibody response due to the oral administration of Inmunair ${ }^{\circledR}$ could be because Inmunair ${ }^{\circledR}$ activates the B-cells located in the lamina propia, which is the last step in B-cell maturation and, it increases Peyer's patches lymphocyte traffic to the lung to control the infection. Mortality rate percentage, Average weight and conversion index in different chicken groups throughout 35 days before challenge and Zootechnical parameters (Table 8).Generally it can be seen that in the group treated with Inmunair ${ }^{\circledR}$ there is a clear decrease in the percentage of mortality, $4 \%$ for the Inmunair ${ }^{\circledR}$ group, $10 \%$ for Betapolo group, $6 \%$ vaccinated only and $12 \%$ for the untreated group. The conversion index is also better in the group treated with Inumnair ${ }^{\circledR} 1.9$ for experimental dose, 2.04 for recommended dose and 2.13 for Betapolo ${ }^{\circledR}$ group as opposed to 2.24 of the untreated group.

The same trend was observed when analysing the weights, having an average difference of about $190 \mathrm{gm}$ more per bird in group treated with Inmunair ${ }^{\circledR}$, and $70 \mathrm{gm}$ in Betapolo ${ }^{\circledR}$ treatement. Generally, the obtained results indicated that the immunostimulant increase birds immunity, health and performance parameters.

Table (1): Effect of immunostimulants on broiler chicken body weight by grams $(n=5)$.

\begin{tabular}{ccccccccc}
\hline \multirow{2}{*}{$\begin{array}{c}\text { Group } \\
\text { No }\end{array}$} & $\begin{array}{c}\text { Immuno- } \\
\text { stimulants }\end{array}$ & ND & \multicolumn{7}{c}{ Body weight (gm)/ week } \\
\cline { 4 - 9 } & & $\mathbf{0}$ & $\mathbf{1}$ & $\mathbf{2}$ & $\mathbf{3}$ & $\mathbf{4}$ & $\mathbf{5}$ \\
\hline 1 & - & - & $50.5 \pm 0.60$ & $163 \pm 1.86 \mathrm{~b}$ & $382.5 \pm 2.81 \mathrm{~b}$ & $673.5 \pm 4.83 \mathrm{~b}$ & $1175.5 \pm 14.71 \mathrm{c}$ & $1588 \pm 28.56 \mathrm{c}$ \\
2 & - & + & $51.8 \pm 0.71$ & $161.5 \pm 1.50 \mathrm{~b}$ & $377.5 \pm 3.18 \mathrm{~b}$ & $673.5 \pm 5.63 \mathrm{~b}$ & $1168.5 \pm 15.97 \mathrm{c}$ & $1591 \pm 29.42 \mathrm{c}$ \\
3 & IMR & + & $50.4 \pm 0.86$ & $170.5 \pm 3.20 \mathrm{a}$ & $405 \pm 6.58 \mathrm{a}$ & $711 \pm 9.27 \mathrm{a}$ & $1268 \pm 18.81 \mathrm{a}$ & $1780 \pm 18.31 \mathrm{a}$ \\
4 & IMR & + & $51.8 \pm 1.03$ & $171 \pm 1.80 \mathrm{a}$ & $403.5 \pm 4.48 \mathrm{a}$ & $695 \pm 9.28 \mathrm{ab}$ & $1248 \pm 17.75 \mathrm{ab}$ & $1776 \pm 13.70 \mathrm{a}$ \\
5 & Betapolo & + & $50.4 \pm 0.91$ & $166.5 \pm 1.67 \mathrm{ab}$ & $402 \pm 4.84 \mathrm{a}$ & $694 \pm 7.45 \mathrm{ab}$ & $1203 \pm 20.52 \mathrm{bc}$ & $1660 \pm 26.00 \mathrm{~b}$ \\
\hline
\end{tabular}

Each value represents mean \pm S.E.

\#: Significant variation between groups (ANOVA test at $\mathrm{P} \leq 0.05$ ).

Different superscript letters $\mathrm{a}, \mathrm{b}$ and $\mathrm{c}$ denote significant variation respectively by LSD at $\mathrm{P} \leq 0.05$.

Table (2): Mean $\mathrm{HI}$ titres to Newcastle disease virus in broiler chickens treated with immunostimulants( $(\mathrm{n}=5)$.

\begin{tabular}{cccccccc}
\hline \multirow{2}{*}{ Group No } & \multicolumn{3}{c}{ Treatment } & \multicolumn{5}{c}{ HI- $\log _{\mathbf{2}} /$ age in weeks } \\
\cline { 2 - 8 } & Immuno-stimulants & ND vaccine & $\mathbf{1}$ & $\mathbf{2}$ & $\mathbf{3}$ & $\mathbf{4}$ & $\mathbf{5}$ \\
\hline 1 & - & - & $6.1 \pm 0.38$ & $2.8 \pm 0.30$ & $\# 1.3 \pm 0.21 \mathrm{c}$ & $\# 0.5 \pm 0.17 \mathrm{c}$ & $\# 0 \mathrm{~d}$ \\
2 & - & + & $5.8 \pm 0.25$ & $2.2 \pm 0.41$ & $6.3 \pm 0.15 \mathrm{ab}$ & $5.8 \pm 0.49 \mathrm{~b}$ & $4.2 \pm 0.25 \mathrm{c}$ \\
3 & IMR (b) & + & $6.1 \pm 0.23$ & $3 \pm 0.39$ & $6.3 \pm 0.18 \mathrm{a}$ & $7 \pm 0.26 \mathrm{a}$ & $5.4 \pm 0.43 \mathrm{~b}$ \\
4 & IMR (a) & + & $6 \pm 0.33$ & $3.2 \pm 0.34$ & $5.5 \pm 0.58 \mathrm{~b}$ & $8 \pm 0.21 \mathrm{~b}$ & $6.4 \pm 0.37 \mathrm{a}$ \\
5 & Betapolo & + & $6 \pm 0.30$ & $2.2 \pm 0.23$ & $6.4 \pm 0.23 \mathrm{ab}$ & $5.5 \pm 0.52 \mathrm{~b}$ & $5.9 \pm 0.31 \mathrm{~b}$ \\
\hline
\end{tabular}

\#: Significant variation between groups (ANOVA test at $\mathrm{P} \leq 0.05$ ).

Different superscript letters $a, b, c$ and $d$ denote significant variation respectively by LSD at $\mathrm{P} \leq 0.05$

Table (3): Thymic index of the broiler chicken group received immunstimulant and ND vaccine as well as control group.

\begin{tabular}{cccccc}
\hline Group No & Immuno- stimulants & ND vaccine & 10 days & 19 days & 30 days \\
\hline 1 & - & - & $\# 3.367 \pm 0.121 \mathrm{~b}$ & $\# 2.79 \pm 0.249 \mathrm{c}$ & $\# 3.177 \pm 0.169 \mathrm{c}$ \\
2 & - & + & $3.376 \pm 0.121 \mathrm{~b}$ & $3.764 \pm 0.321 \mathrm{~b}$ & $3.933 \pm 0.320 \mathrm{bc}$ \\
3 & IMR & + & $4.405 \pm 0.083 \mathrm{a}$ & $4.820 \pm 0.247 \mathrm{a}$ & $4.886 \pm 0.467 \mathrm{ab}$ \\
4 & IMR & + & $4.415 \pm 0.083 \mathrm{a}$ & $4.790 \pm 0.247 \mathrm{a}$ & $4.952 \pm 0.444 \mathrm{a}$ \\
5 & Betapolo & + & $4.34 \pm 0.057 \mathrm{a}$ & $3.780 \pm 0.159 \mathrm{~b}$ & $4.384 \pm 0.277 \mathrm{ab}$ \\
\hline
\end{tabular}

Each value represents mean \pm S.E.

\#: Significant variation between groups by ANOVA test at $\mathrm{P} \leq 0.05$.

Different superscript letters $\mathrm{a}, \mathrm{b}$ and $\mathrm{c}$ denote significant variation respectively by LSD at $\mathrm{P} \leq 0.05$. 
Table (4): Splenic index of broiler chicken group received immunstimulant and ND vaccine as well as control group.

\begin{tabular}{cccccc}
\hline Group No & Immuno- stimulants & ND vaccine & 10 days & 19 days & 30 days \\
\hline 1 & - & - & $\# 0.411 \pm 0.013 \mathrm{c}$ & $\# 0.583 \pm 0.028 \mathrm{~b}$ & $0.655 \pm 0.021$ \\
2 & - & + & $0.419 \pm 0.013 \mathrm{c}$ & $0.63 \pm 0.019 \mathrm{~b}$ & $0.681 \pm 0.034$ \\
3 & IMR & + & $0.562 \pm 0.028 \mathrm{~b}$ & $0.860 \pm 0.037 \mathrm{a}$ & $0.789 \pm 0.012$ \\
4 & IMR & + & $0.570 \pm 0.028 \mathrm{~b}$ & $0.852 \pm 0.037 \mathrm{a}$ & $0.771 \pm 0.032$ \\
5 & Betapolo & + & $0.661 \pm 0.042 \mathrm{a}$ & $0.952 \pm 0.057 \mathrm{a}$ & $0.726 \pm 0.051$ \\
\hline
\end{tabular}

\#: Significant variation between groups by ANOVA test at $\mathrm{P} \leq 0.05$.

Different superscript letters $\mathrm{a}, \mathrm{b}$ and $\mathrm{c}$ denote significant variation respectively by LSD at $\mathrm{P} \leq 0.05$.

Table (5): Bursal index of broiler chicken group received immunstimulant and ND vaccine as well as control group.

\begin{tabular}{cccccc}
\hline Group No & Immuno- stimulants & ND vaccine & 10 days & 19 days & 30 days \\
\hline 1 & - & - & $1.709 \pm 0.052$ & $\# 1.708 \pm 0.228 \mathrm{~b}$ & $\# 0.718 \pm 0.079 \mathrm{c}$ \\
2 & - & + & $1.712 \pm 0.52$ & $2.127 \pm 0.216 \mathrm{ab}$ & $1.271 \pm 0.093 \mathrm{~b}$ \\
3 & IMR & + & $1.874 \pm 0.110$ & $2.679 \pm 0.308 \mathrm{a}$ & $1.721 \pm 0.160 \mathrm{a}$ \\
4 & IMR & + & $1.854 \pm 0.110$ & $2.664 \pm 0.308 \mathrm{a}$ & $1.402 \pm 0.157 \mathrm{ab}$ \\
5 & Betapolo & + & $2.143 \pm 0.298$ & $1.889 \pm 0.040 \mathrm{~b}$ & $1.415 \pm 0.198 \mathrm{ab}$ \\
\hline
\end{tabular}

Each value represents mean \pm S.E.

\#: Significant variation between groups by ANOVA test at $\mathrm{P} \leq 0.05$.

Different superscript letters $a, b$ and $c$ denote significant variation respectively by LSD at $\mathrm{P} \leq 0.05$.

Table (6): Daily distribution of morbidity and mortality in challenged chickens.

\begin{tabular}{|c|c|c|c|c|c|c|c|c|c|c|c|c|c|c|c|c|}
\hline \multirow{2}{*}{$\begin{array}{c}\text { Group } \\
\text { No } \\
\end{array}$} & \multicolumn{2}{|c|}{ Treatment } & \multirow{2}{*}{ Observation } & \multicolumn{11}{|c|}{ Days post-challenge } & \multirow[t]{2}{*}{ Total } & \multirow[t]{2}{*}{$\%$} \\
\hline & I.S & Vacc. & & 1 & 2 & 3 & 4 & 5 & 6 & 7 & 8 & 9 & 10 & 11-21 & & \\
\hline \multirow{2}{*}{1} & & & Diseased No & & & 2 & 5 & 7 & 3 & 2 & - & - & - & - & 19 & 95 \\
\hline & - & - & Died No. & & & 1 & 1 & 3 & 7 & 7 & 1 & - & - & - & 20 & 100 \\
\hline \multirow{2}{*}{2} & & \multirow{2}{*}{+} & Diseased No & & & 1 & 2 & 3 & 1 & - & - & - & - & - & 7 & 35 \\
\hline & - & & Died No. & & & 1 & 1 & 2 & 1 & - & - & - & - & - & 5 & 25 \\
\hline \multirow{2}{*}{3} & \multirow{2}{*}{ IMR (b) } & \multirow{2}{*}{+} & Diseased No & & & & & 1 & 2 & 1 & - & - & - & - & 4 & 20 \\
\hline & & & Died No. & & & & & & 1 & - & - & - & - & - & 1 & 5 \\
\hline \multirow{2}{*}{4} & \multirow{2}{*}{ IMR(a) } & \multirow{2}{*}{+} & Diseased No & & & & & 1 & 3 & 2 & - & - & - & - & 6 & 30 \\
\hline & & & Died No. & & & & 1 & 1 & - & 1 & - & - & - & - & 3 & 15 \\
\hline \multirow{2}{*}{5} & \multirow{2}{*}{ Betapolo } & \multirow{2}{*}{+} & Diseased No & & & & 1 & 2 & 2 & 1 & 1 & - & - & - & 7 & 35 \\
\hline & & & Died No. & & & & & 1 & 1 & 1 & 1 & 1 & - & - & 5 & 25 \\
\hline
\end{tabular}

Table (7): Protection rates to ND virus challenge in immunostimulants treated and vaccinated broiler chickens at $7^{\text {th }}$ week of age.

\begin{tabular}{ccccccc}
\hline $\begin{array}{c}\text { Group } \\
\text { No }\end{array}$ & $\begin{array}{c}\text { Immuno- } \\
\text { stimulants }\end{array}$ & $\begin{array}{c}\text { ND } \\
\text { vaccine }\end{array}$ & $\begin{array}{c}\text { Total No } \\
\text { of birds }\end{array}$ & $\begin{array}{c}\text { No of dead } \\
\text { birds }\end{array}$ & $\begin{array}{c}\text { No of } \\
\text { survived birds }\end{array}$ & Protection \% \\
\hline 1 & - & - & 20 & 20 & 0 & 0 \\
2 & - & + & 20 & 5 & 15 & 75 \\
3 & IMR & + & 20 & 1 & 19 & 95 \\
4 & IMR & + & 20 & 2 & 18 & 90 \\
5 & Betapolo & + & 20 & 5 & 15 & 75 \\
\hline
\end{tabular}

Table (8): Effect of the immunostimulants on different zootechnical parameters of broiler chickens.

\begin{tabular}{lccccc}
\hline Factor & Control group & Vaccine & IMR(b)+Ve & IMR(a)+Ve & Betapolo+Ve \\
\hline Total number of casualties & 50 & 50 & 50 & 50 & 50 \\
mortality rate & 12 & 6 & 4 & 4 & 10 \\
Average feed consumed & 3.56 & 3.50 & 3.60 & 3.64 & 3.54 \\
chicken (kg) & 1.588 & 1.591 & 1.780 & 1.776 & 1.660 \\
Average body weight & 2.24 & 2.20 & 1.90 & 2.04 & 2.13 \\
Feed conversion rate & & & & & \\
\hline
\end{tabular}
(a): IMR $2^{\text {nd }}$ dose after vaccination.
(b): IMR $2^{\text {nd }}$ dose before vaccination 


\section{References}

Acevedo, A. M.; Pedroso, M. and Miranda, I. (2001): Effect of treatment with lineal particulate beta1-3 glucan by oral route on humoral response to Newcastle vaccine in chickens. Revista-Cubana-de-Ciencia-Avicola. 25(2):107112.

Afify, M. A. (1990): Studies on the role of some immunostimulants in using poultry vaccines. $\mathrm{Ph}$. D. Thesis, Faculty of Veterinary Medicine, Cairo Univ., Egypt.

Anguera, Caldentey, Marca, Torras(1996): Eficacia del inmunomodulador Inmunair $^{\circledR}$ como potenciador de la respuesta inmunitaria en pollitas de recría. XXXIII Symposium de Avicultura. Toledo, 16-18 Oct.

Anon, (1971): Methods for examining poultry biologics and for identifying avian pathogens. Nat. Acad. Sci., Washington, D.C.

Awaad, M. H. H.; Zouelfakar, S. A.; EL-Shazly, O. A.; Afify, M. A. and Shaheed, I. B. (2000): Immunomodulatory properties of inactivated probacterium granulosum (IMR)®. In non-immunosuppressed chickens. J. Egypt. Med. Assoc., 66(7):137-148.

Chihara, G.; Maeda, Y. Y.; and Hamuro, J. (1983): Current status and perspectives of immunomodulators of microbial origin. Int. J. Tissue Reactiv., 4(3):207-225.

Fleischer, L. G.; Gerber, G.; Liezenga, R. W.; Lippert, E.; Scholl, M.A.; and Westphal, G. (2000): Blood cells and plasma proteins of chickens fed a diet supplemented with beta-D-glucan. Arch. Animal Nut., 53(1):59-73.
Flo, J.; Goldman, H.; Roux, M. I. and Massouh, E. (1996): Oral administration of bacterial immunomodulator enhances the immune response to cholera toxin. Vaccine, 14:1167-1173.

Houot, O. (1985): interpretation of clinical laboratory test. cited By siest, G., Henny,J.; schiele, F. and Young, D. s. in panphlete of Bio Merieux, France.

Jacobs, D. M. (1981): Immunomodulatory effects of bacterial LPS. J. Immunopharmacol., 3(2):119-132.

Nutt, M. P. and Herrick, C. A. (1952): A new blood diluent for counting the leucocytes of the chickens. Poult. Sci., 31: 735-738.

Poli, G. (1984): Immunomodulators. In Adjuvents, Interferon and Non-Specific Immunity, Eds Cancellotti, F.M. and Galassi, D., pp. 111-126. EEC, Luxembourg.

Shible, A. and Reda, I. M. (1976): Cited by Khaphgy, A.U. (1977) thesis MVSc, Facult. Vet. Med., Cairo Univ., Egypt.

Steel, R. G. D. and Torrie, J. H. (1960): Principles and procedures of statistics. McGraw-Hill Book Comp. Inc. New York, Toronto, London, pp.99-131.

Vanjaykumer, D. S.; Ramakisha, O. and Haragopel, U. (1983): Corynebacterium Parvum induced regression of horn cancer in a bullock. Vet. Med. Small Animal Clinician, 78(12):1905-1908.

Ying, L.; YuMing, G.; JianMin, Y. and Wei, N. (2003): Effects of beta -1, 3/1, 6-glucan on performance and immune response of broilers. J. China Agri. Univ., 8 (1): 91-94.

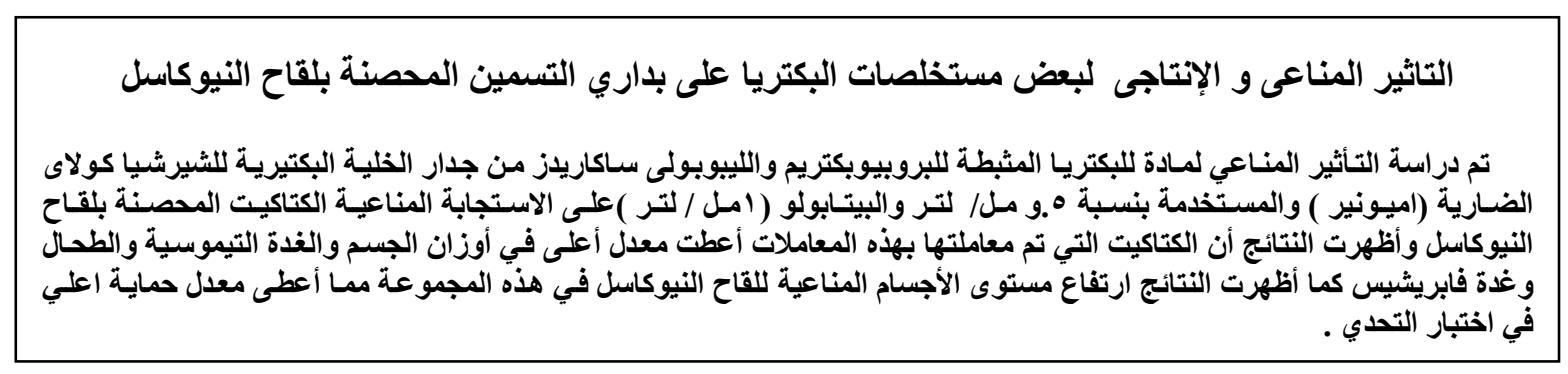

